\author{
Xu Bian \& Jin'e He (USA/China)
}

\title{
The Impact of Morphological Awareness on Vocabulary Knowledge of Advanced Chinese EFL Learners
}

\begin{abstract}
Summary: The study explored the inter- and intra-relationship between two multi-dimensional constructs, morphology and vocabulary. Fifty five senior students from a Chinese university majoring in English were assessed on five variables: compounding knowledge, real-word derivational knowledge, pseudoword derivational knowledge, reading vocabulary knowledge and listening vocabulary knowledge. Using t-test, correlation and hierarchical regression, the study found that aural and written vocabulary knowledge was distinctive but related; real-word derivational knowledge correlated with both two facets of vocabulary knowledge; compounding knowledge and real-word derivational knowledge made unique contributions to performance on the listening vocabulary test.
\end{abstract}

Keywords: morphological awareness; compound awareness; derivational awareness; listening vocabulary; reading vocabulary

Zusammenfassung (Xu Bian \& Jin'e He: Der Einfluss des morphologischen Bewusstseins auf die Wortschatzkenntnisse fortgeschrittener chinesischer EFL-Lernender): Die Studie untersuchte die Inter- und Intra-Beziehung zwischen zwei multidimensionalen Konstrukten, Morphologie und Vokabular. Fünfundfünfzig ältere Studier ende einer chinesischen Universität mit Schwerpunkt Englisch wurden auf fünf Variablen bewertet: Compounding-Wissen, Ableitungswissen aus dem realen Wort, Pseudowort-Ableitungswissen, Vokabeln lesen und Vokabeln lernen. Mit Hilfe von t-Test, Korrelation und hierarchischer Regression fand die Studie heraus, dass das Wissen über das Hörverständnis und das schriftliche Vokabular unverwechselbar, aber verwandt war; das Wissen über die Ableitung von Realwörtern korrelierte mit beiden Facetten des Vokabularwissens; das Zusammensetzen von Wissen und das Wissen über die Ableitung von Realwörtern erbrachte einzigartige Beiträge zur Leistung beim Test des Hörvokabulars.

Schlüsselwörter: morphologisches Bewusstsein, zusammengesetztes Bewusstsein, Ableitungsbewusstsein, Hörvokabular, Lesevokabular

Резюме (Ксу Биан и Йинье Хе: Влияние морфологическое сознания на знания словарного запаса продвинутых китайских учащихся, изучающих английский язык как иностранный): Работа исследовала внутреннюю и внешнюю связь между двумя многомерными конструктами, морфологией и словарным запасом. Двадцать пять старшекурсников китайского университета с основной специальностью «английский язык» оценивались по пяти переменным: знание контаминации, деривационное знание реального слова, деривационное знание псевдослова, чтение слов и изучение слов. С помощью $t$-теста, корреляции и иерархической регрессии работа установила, что знание аудированного и письменного вокабулара было индивидуально, но схоже; знание о деривации реальных слов коррелировала с обеими гранями знаниями вокабуляра; сочетание знания и знания о деривации реальных слов показало уникальные успехи при тестировании аудированного вокабуляра.

Ключевые слова: морфологическое сознание, комплексное сознание, деривационное сознание, аудированный вокабуляр, вокабуляр чтения

\section{Introduction}

Vocabulary knowledge is built upon three sources of information, definition, context, and word parts, according to the metalinguistic hypothesis proposed by Nagy (2007). Word parts, also known 
as morphemes, are the smallest units of meaning. Three thorough analyses of English words (Bird, 1987; 1990, cited in Nation, 2013; Nagy \& Anderson, 1984) have demons trated that the majority of English words can be broken down into meaningful parts. Afterward, substantial research conducted on English-native speaking children has well documented the robust link between morphological awareness (MA) and vocabulary knowledge (e.g., Carlisle, 2000; Carlisle \& Fleming, 2003; McBride-Chang, Wagner, Muse, Chow, \& Shu, 2005; Nagy, Berninger, \& Abbott, 2006; Nagy, Berni nger, Abbott, Vaughn, \& Vermeulen, 2003). Morphological awareness is defined as the ability to reflect upon and manipulate morphemes; in other words, the ability to cut words into smaller meaningful parts such as affixes and roots.

Vocabulary is critical to billions of English as a foreign language (EFL) learners as well. Knowledge of how English creates words from morphemes is essential. However, merely a few studies to date have investigated the relationship between MA and vocabulary knowledge in the context of EFL. Given that the significant correlation emerged in the limited previous res earch, the details regarding various facets of morphology and different types of vocabulary knowledge are still absent. Thus, the purpose of the present study was to explore the inter- and intra-relationships among compounding, derivational morphology and listening and reading vocabulary knowledge. Terms, phonological and orthographical vocabulary, have been used in previous research to refer to liste ning and reading vocabulary, so they all are interchangeable in the present study.

\section{Morphology and Vocabulary in English Native Speakers, English Language Learners, and EfL Learners}

It is necessary to el aborate the two core concepts, morphology and vocabulary, and their relationship before reviewing the literature in the field.

In English there are three types of morphology, derivational, compounding and inflectional. Derivational morphology refers to knowledge of affixes (e.g., the il in illegal; the sion in decision); compounding means two or more than two words constitute one word (e.g., greenhouse); inflectional morphology focuses on grammatical changes in words (e.g., the $s$ in boys or the ed in worked). According to Nagy and Anderson (1984), there are 105,044 compounds, 99,547 inflected words, and 70,888 derivational words.

Vocabulary, likewise, is a multi-fac et concept. The theo retical framework proposed by Nation (2013) highlights three aspects involved in knowing a word, form, meaning, and us e. Form includes reco gnizing a word in both spoken and written language as well as word parts; meaning contains knowing the concept, referents and associations plus connecting form and meaning; use refers to knowledge about grammatical functions, collocations, and constraints. Two assumptions can be made based on the Nation's fram ework: a) vocabulary knowledge of written and spoken forms of words may be distinguished, particularly in the context of EF L; b) a learner's vocabulary knowledge means that $\mathrm{s} / \mathrm{he}$ can perceive the forms of a word and access some aspects of meaning attached to the word form (Mizumoto \& Shimamoto, 2008). However, the overview of research in the field of EFL learners' vocabulary knowledge demonstrates that the orthographic vocabulary tests have dominated instrument employed in the past, and only three phonological vocabulary tests (e.g., Fountain \& Nation, 2000; Milton \& Hopkins, 2006; McLean, Kramer \& Beglar, 2015) are available thus far. In addition, researchers have been more interested in the relationship between listening vocabulary and various language skills such as speaking, listening, reading, and writing. With regard to what factors contribute to dev elopment of listening vocabulary (Zeeland, 2017), it has not garnered sufficient attention from scholars. 
In term of the relationship between morphology and vocabulary knowledge, evidence so far suggests that morphological awareness and vocabulary knowledge are highly correlated but distinct despite their shared involvement with the semantic aspects of language mentioned above.

Findings from Carlisle's (2000) study examining 60 English-native speaking elem entary schoolers have indicated the significant relation of MA and vocabulary knowledge according to the correl ation analysis. Two morphological tasks used in the study focused on derivational words only; vocabulary knowledge was assessed by employing two tests, orally explaining the meaning of a word and reading a word. Results the regression analysis also demonstrated that the task of producing derivational words made a unique contribution to the vocabulary meaning test score.

Carlisle and Fleming (2003) provided further evidence supporting the strong correlation between MA and vocabulary knowledge by examining 60 elem entary students' performance and deploying the same morphology and vocabulary measures as those in Carlisle's (2000) study. Yet the longitudinal study did not report the contribution of morphology to vocabulary knowledge because it focused on the development of the lexical processes and its relation with reading comprehension.

The robust relation of MA and vocabulary has surfaced in McBride-Chang and colleagues' (2005) study which looked at 220 young American children's performance on the expressive vocabulary test and two morphology tasks, morpheme identification and making compounds. Additionally, the research showed that scores of the two different morphological tasks were uniquely predictive to their vocabulary knowledge according to the hierachical regression analysis.

Nagy and colleagues' (2006) research confirmed the relationship between MA and vocabulary documented in previous research, demonstrating that 607 participants' MA was significantly linked with but also a unique predictor to vocabulary knowledge by using structural equation modeling framekwork. The study also extended prior findings by administering the test of inflectional and derivational morphology and the written lexical meaning test to upper elem entary schoolers and middle schoolers.

Another study by Nagy and colleagues (2003) investigating the role of morphology on vocabulary knowledge of 195 at-risk 2nd-graders and 4th-graders suggested MA's correlation with and predictive power to the former group's vocabulary knowledge and the only association in the latter group by employing the correlational analysis and the stuructural equation model. Researchers assessed students' morphology knowledge including inflection, derivation and compounds and vocabulary knowledge including orally explaining the meaning of words and reading words aloud.

The limited research conducted with English language learners (ELL) and English as a foreign language (EFL) learners has furthered unders tanding about the relation of morphology and vocabulary knowledge. Goodwin (2011) found that elementary Spanish ELLs' derivational knowledge predicted their performance of orally naming a picture and accessing meanings of written words after controlling for other confounds. Another study, Kieffer and colleagues (2013), reported the significant contribution derivational knowledge made to Spanish ELL middle schoolers' vocabulary size.

ESL learners' vocabul ary acquisition and development has garnered a lot of scholars' attention, but to date only a few studi es looking at the impact of morphology on literacy have presented a picture about the relation of MA and vocabulary knowledge. Jeon's (2011) study reported the association between accessing Korean meanings of English words and knowledge of affixes by observing 188 Korean teenagers and conducting the correlational analysis. Zhang and Koda (2012, 2013, 2014) confirmed Jeon's finding but also extended it by examining Chinese young and adult EFL learners' morphological knowledge and lexical knowledge. The study (2012) suggests that 130 graduate students' knowledge on English derived words was powerfully predictive to their vocabulary breath and depth based on the baseline structural model. Findings from the one (2013) carried out among 245 elementary students indicate that all three facets of morphology, inflection, derivation and compounding were correlated with aural vocabulary knowledge assessed by sel ecting a picture for the target English word according to the correlational analysis. Another study (2014) focusing 
on 245 young Chinese EFL learners documented the significant correlation between scores of the reading vocabulary test and performance on the test of morphology including derivation and compounding.

Studies discussed above have shown the consensus among scholars that morphology is linked to lexicon des pite nuances caused by focusing on different aspects of morphology and vocabulary. In the meantime, it is worth noting that listening vocabulary/recognizing the spoken form of a word has not been thoroughly examined in prior research, particularly in the EFL field. EFL learners orthographic and phonological lexical knowledge can differ significantly according to a few empirical studies (e.g., Milton \& Hopkins, 2006; Mizumoto \& Shimamoto, 2008).

\section{Research Questions:}

1. Do EFL learners' listening vocabulary and reading vocabulary differ?

2. What is the relationship of the two types of vocabul ary and different facets of morphology? What aspect of morphology would contribute uniquely to listening and reading vocabulary respectively?

\section{Method}

\section{Participants}

Participants were all 55 (50 female, 5 mal e) English majored seniors on the English literature track from a university located in Guangzhou, China, with an average age of 22. Their formal English ed ucation started when they were in Grade 3 in elementary school. Additionally, they would take the Test for English Majors Band 8, a high-stakes proficiency exam, in the last semester at college. That is, they were fairly advanced learners of English.

\section{Instruments}

Reading vocabulary test. The Vocabulary Levels Tests designed by Schmitt et al. (2001) was used to assess participants' knowledge of written words. Five parts constituted it, repres enting five levels of word frequency in English: 2,000 words, 3,000 words, 5,000 words, university word level, and 10,000 words. Three of the five levels, 2,000, 3,000, and 10,000, were excluded because they were unable to effectively measure participants' vocabulary knowledge. There were ten clusters in each section and each cluster contained six words and three brief definitions. Besides, one practice item was included. The reliability of the two sections reported by authors in previous research was .927 and .960 respectively.

Listening vocabulary test. The Listening Vocabulary Levels Test designed by McLean et al. (2015) was deployed to evaluate participants' knowledge of words presented aurally. Like the written vocabulary knowledge test, it consisted of five sections as well, the first five 1,000 -frequency levels and the Academic Word List (AWL). Due to participants' English proficiency, only the 5,000 level and AWL were adopted in this study. The test used the multiple-choice format and each item had four choices, from which each examinee chose the response with the closest meaning to the target word. The four choices were provided in examinees' native language in order to control the confounder of foreign-language reading ability. For example, examinees heard: 'School: This is a big school.' A. 银行 (bank); B. 海洋动物 (sea animal); C. 学校 (school); D. 家 (family). The author of the present study wrote up all choices in Chinese based on the principle that distractors should be se- 
mantically, phonologically, and orthographically close to the correct answer, whereas the choices in the original test are in Japanese. The audio was heard once only. The reliability of the original test was .97 based on the Rash item analysis.

Derivational suffix multiple choice test. The instrument was adopted from Mahony's (1994) study. It was designed to assess subjects' knowledge of the syntactic category of comm on Latin and Greek suffixes. It consists of two parts, the syncat-real test and the syncat-nonce test. Each part is composed of 27 sentences containing a blank and followed by four real words or ps eudo words which are different derivations of the same stem; that said, the answer choices differ from each other only in their suffixes. For example, the cost of keeps going up. A. electric B. electrify C. electricity D. electrical. The meeting was highly and invigorating. A. loquarial B. loquarify C. loquarialize D. loquarialism. The answer choices in the syncat-nonce test are made up of a real Latin or Greek bound stem and a real suffix between which a nonsense syllable is inserted. The kno wledge of three types of suffixes is measured, nouns, verbs, and adjectives. The purpos e of the syncatnonce test was to minimize the confounding of existing lexical knowledge that is more related to real-word morphology and contextual clues. Inflectional morphemes were not included because Tighe and colleagues (2015) found that inflectional and derivational morphology did not represent separate facets of MA. The test was presented visually only, that is, students read it silently and administers did not read the questions aloud for them.

Compounding test. The task is was adapted from Nagy et al. (2003), Pasquarella et al. (2011), Ramirez et al. (2011), Wang et al. (2006), and Zhang and Koda (2013). The reliability reported in the last four studies ranges ranged from .61 to .91. Participants chose a better compound fitting the riddle. For example, Which is a better name for a bee that lives in the grass: a grass bee or a bee grass? The correct answers in each riddl es had reversed modifier-head relationships. The task consisted of fifteen riddles, plus two practice items.

\section{Data collection procedures}

Data were collected in the participants' regular English classes at the end of their first semester of the fourth year, December 2016. All tests were paper-and-pencil and administered to students in a whole class format. The listening vocabulary test was administered first, followed by the reading vocabulary, compound, and derivation.

\section{Results}

\section{Descriptive statistics}

Table 1 presents names of the ins truments us ed in this study, their full scores, and their descriptive statistics. . Score distributions of all tests and subtests except the pseduoword derivation test were normal. The log transformation was performed but no significant effect was found between the normalized and original data.

Table 1: Descriptive Statistics

\begin{tabular}{lr|r|r}
\hline & Full score & Mean & Std. Deviation \\
\hline Listening Vocab & 54 & 41.20 & 4.531 \\
\hline Reading Vocab & 60 & 53.80 & 4.919 \\
\hline Compound & 15 & 10.80 & 2.592 \\
\hline Suffix & 54 & 48.95 & 4.942 \\
\hline
\end{tabular}




\begin{tabular}{ll|l|l}
\hline Real-word Suffix & 27 & 24.40 & 2.408 \\
\hline Pseudoword Suffix & 27 & 24.55 & 3.042 \\
\hline
\end{tabular}

To answer the first research question, a dependent t-test was conducted to compare knowledge of vocabulary in modalities of listening and reading. There was a significant difference in the scores for listening $(M=41.2, S D=4.531)$ and reading conditions $(M=53.8, S D=4.919) ; t(54)=-16.658$, $\mathrm{p}=.000$. These results suggest that how words are presented, auding or written, do es have an effect on accessing meanings of words. The effect size was 0.91 .

To address the second research question, correlation analysis was first performed that showed the relationship among variables (Table 2). Listening vocabulary and reading vocabulary differed by were significantly associated with each other $(\mathrm{r}=.298, \mathrm{p}<0.05)$. Listening vocabulary was correlated with compounding $(\mathrm{r}=.415, \mathrm{p}<0.01)$, and with the real-word suffix task $(\mathrm{r}=.415, \mathrm{p}<0.01)$, but not with the pseudoword suffix task or the combined suffix scores. Likewise, the correlation between derivational knowledge of real words and reading vocabulary scores emerged $(r=.305, p<0.05)$, whereas scores of the compound test and pseudo-word derivation test were insignificantly correlated with reading vocabulary test scores.

Table 2: Correlations among Listening Vocab, Reading Vocab, Compound, Real-word Suffix and Pseudoword Suffix

\begin{tabular}{|c|c|c|c|c|c|c|}
\hline & 1 & 2 & 3 & 4 & 5 & 6 \\
\hline 1 Listening Vocab & -- & & & & & \\
\hline 2 Reading Vocab & $.298^{*}$ & -- & & & & \\
\hline 3 Compound & $.415^{* *}$ & .165 & -- & & & \\
\hline 4 Suffix & .192 & .248 & .197 & -- & & \\
\hline 5 Real-word Suffix & $.415^{* *}$ & $.305^{*}$ & $.268^{*}$ & $.881^{* *}$ & -- & \\
\hline 6 Pseudoword Suffix & $-.016 * *$ & .161 & .108 & $.927^{* *}$ & $.640^{* *}$ & -- \\
\hline
\end{tabular}

Based on the results from the correlational analysis described above, hi erarchic al regression analysis was performed to investigate the unique contribution of compound knowledge and real-word derivation knowledge to performances on listening and reading vocabulary respectively. Table 3 summarizes the results of the analysis including three variables, reading vocabulary, real-word derivation, and compounding. Both morphological variables, real-word derivation and compounding, made significant contributions to listening vocabulary, but reading vocabulary was not a predictor despite its correl ation with listening vocabulary. Table 4 pres ents the results of two ind ependent variables, real word derivation and listening vocabulary, and the dependent variable, reading vocabulary. None of the predictors makes a significant unique contribution to reading vocab ulary. 
Table 3: Hierarchical Regression Analysis for Three Variables Predicting Listening Vocab ulary

\begin{tabular}{lllllll}
\hline Model & Predictor & $R^{2}$ & Adjusted $R^{2}$ & $R^{2}$ change & Beta & Sig \\
\hline 1 & $\begin{array}{l}\text { Reading vo- } \\
\text { cab }\end{array}$ & .089 & .071 & .089 & .160 & .204 \\
\hline 2 & $\begin{array}{l}\text { Real word } \\
\text { derivation }\end{array}$ & .204 & .174 & $.116^{*}$ & .282 & .031 \\
\hline 3 & Compound & .295 & .253 & $.090^{*}$ & .313 & .014 \\
\hline${ }^{*} p<0.05,{ }^{* *} p<0.01$ & & & & &
\end{tabular}

Table 4: Hierarchical Regression Analysis for Two Variables Predicting Reading Vocabulary

\begin{tabular}{lllllll}
\hline Model & Predictor & $R^{2}$ & Adjusted $R^{2}$ & $R^{2}$ change & Beta & Sig \\
\hline 1 & $\begin{array}{l}\text { Real word } \\
\text { derivation }\end{array}$ & .093 & .076 & .093 & .220 & .129 \\
\hline 2 & $\begin{array}{l}\text { Listening } \\
\text { vocab }\end{array}$ & .129 & .095 & .035 & .206 & .153 \\
\hline$* p<0.05, * * p<0.01$ & & & & &
\end{tabular}

${ }^{*} p<0.05,{ }^{* *} p<0.01$

\section{Discussion}

\section{Phonological vocabularyand orthographical vocabulary}

Although Nation (2013) posited that recognizing words in spoken language is one of the multi-layer concept of vocabulary knowledge, testing ESL learners' aural lexicon by using a well-constructed tool is rather recent. The finding that Chinese EFL learners' phonological vocabulary and orthographical knowledge is distinct but correlated is in line with findings from the limited prior res earch in the field (e.g., Milton \& Hopkins, 2006; Milton et al., 2010; Mizumoto \& Shimamoto, 2008). In addition, results from the current study have indicated that advanced Chinese EFL learners' written vocabulary knowledge exceeds the aural vocabulary knowledge, which echoes findings from res earch by Milton and Hopkins (2006) and Mizumoto and Shimamoto (2008) respectively whose pa rticipants were EFL learners speaking Greek, Arabic and Japanes e. However, it is necessary to point out that it is one of plausible interpretation of the results. Given that the frequency of vocabulary involved in the listening and reading vocabulary tests is identical, the formats of the two tests differ, which may lead to the performance gap. The distinctiveness and correlation between the two aspects of vocabulary knowledge suggest that they should be assessed in different ways, which could provide a holistic view about EFL learners' vocabulary knowledge.

\section{Morphological awareness, listening vocabulary and reading vocabulary}

English is a morphophonemic language where the majority of words are derivational. Scholars have realized that both vocabulary and morphology are multi-dimensional and raised questions about the interrelationship among various facets of morphology and aspects of vocabulary (e.g., Tighe \& Schatschneider, 2015). Findings in the present research address such questions.

With regard to derivational morphology, prior research with English native speakers has showed that it is a powerful predictor of vocabulary knowledge. Results from the present study not only confirm it but also extend it by providing details regarding the relationship. Findings have demonstrated that real word derivation is significantly correlated with both phonological and orthographical vocabulary knowl edge. In addition, it accounts for $11.6 \%$ variance of participants' listening vocabulary test scores. That is, knowledge of derivational morphology could facilitate recogni- 
zing words of the spoken form as it do es to written words. Meanwhile, the marginalized correlation between pseudo-word derivation knowledge and ei ther listening or reading vocabulary aligns with one of findings in Tighe and Schatschneider (2015), that the model excluding the derivational suffix choice test of pesudowords was a good fit to the data.

Compounding morphology is one of the foci in the present study. Results underscore its unique impact on phonological vocabulary knowledge, explaining $9 \%$ of variance of listening vocabulary knowledge, which broadens understanding gained from prior research only examining EFL participants' reading vocabulary knowledge (e.g., Jeon, 2011; Zhang \& Koda, 2014). The unique role compounding morphology has played on listening vocabulary knowledge may be attributed to the fact that compounds are preval ent in Mandarin Chinese. Also, compounding is commonality shared by both Chinese and English where compounds are formed in a similar structure, right-headedness. The cross-linguistic transfer of compound awareness has emerged in previous studies investigating the relation of Chinese-English bilinguals' different types of morphological knowledge and reading abilities (e.g., Pasquarella et al., 2011; Wang, Cheng, \& Chen, 2006). Nevertheless, compounding morphology insignificantly correlated reading vocabulary knowledge in this study, which differs from findings in Jeon (2011) and Zhang and Koda (2014). The reason may lie in the fact that all three studies employed different orthographical vocabulary tests, such as the English-Korean vocabulary test in Jeon's study, a picture selection task in Zhang and Koda's, and the English-English vocabulary test in this study.

Finally, another intriguing finding in this study is that no ne of the three variables, real-word derivation, compounding, and listening vocabulary, accounted for the unique variance of reading vocab ulary knowledge although real-word derivation and listening vocabulary were significantly correlated with reading vocabulary. It, nev ertheless, consolidates the impact of compound awareness on listening vocabulary.

\section{Conclusion}

The current study has begun to shed light on the relations between the two multi-dimensional constructs, morphology and vocabulary. Phonological and orthographical vocabulary knowledge differs but correlates, which can be elaborated from the morphology perspective. Real -word derivational knowledge is associated with vocabulary knowledge in the written and spoken form. Additionally, both real-word derivational knowl edge and compounding knowledge are powerful predictors of listening vocabulary knowledge. The inter- and intra-relationship among the various facets of the two constructs suggests that more measures should be deployed in future research regarding vocabulary and morphology. The findings also have implications to EFL instruction, which need figure out how to improve EFL learners' listening vocabulary knowledge by utilizing their morphology knowledge.

\section{References}

Carlisle, Joanne F. (2000): Awareness of the structure and meaning of morphologically complex words: Impact on reading. In: Reading and Writing: An Interdisciplinary Journal, 12, pp. 169-190.

Carlisle, Joanne F. \& Fleming, Jane (2003): Lexical processing of morphologically complex words in the elementary years. In: Scientific Studies of Reading, 7(3), pp. 239-253.

Fountain, R. L. \& Nation, I.S.P. (2000): A vocabul ary-based graded dictation test. In: RELC Journal, 31, pp. 29-44.

Goodwin, Amanda. (2011): Does meaning matter for reading achievement? Untangling the role of phonological recoding and morphological awareness in predicting word decoding, reading vo- 
cabulary, and reading comprehension achievement for Spanish-speaking English language learners. In: P. J. Dunston, L. B. Gambreel, K. Headley, S. K. Fullerton, P. M. Stecker, V. R. Gillis \& C. C. Bates (Eds.): $60^{\text {th }}$ yearbook of the literacy research association (pp. 77-95). Oak Creek, Wisconsin: Literacy Research Association, Inc.

Jeon, Eun Hee (2011): Contribution of morphological awareness to second-language reading comprehension. In: The Modern Language Journal, 95(ii), pp. 217-235.

Kieffer, Michael J.; Biancarosa, Gina \& Mancilla-Martinez, Jeannette (2013): Roles of morphological awareness in the reading comprehension of Spanish-speaking language minority learners: exploring partial mediation by vocabulary and reading fluency. In: Applied Psycholinguistics, 34, pp. 697-725.

Mahony, Diana L. (1994): Using sensitivity to word structure to explain variance in high school and college level reading ability. In: Reading and Writing: An Interdisciplinary Journal, 6, pp. 19-44.

McBride-Chang, Catherine; Wagner, Richard K.; Muse, Andrea; Chow, Bonnie W.-Y. \& Shu, Hua (2005): The role of morphological awareness in children's English reading and vocabulary acquisition. In: Applied Psycholinguistics, 26, pp. 415-435.

McLean, Stuart; Kramer, Brandon \& Beglar, David (2015): The creation and validation of a listening vocabulary levels test. In: Language Teaching Research. (Retrieved from DOI: $10.1177 / 1362168814567889)$.

Milton, James \& Hopkins, Nicola (2006): Comparing phonological and orthographic vocabulary size: Do vocabulary tests underestimate the knowledge of some learners. In: The Canadian Modern Language Review, 63(1), pp. 127-147.

Milton, James; Wade, Jo \& Hopkins, Nicola (2010): Aural word recognition and oral competence in English as a foreign language. In: R. Chacon-Beltran, C. Abello-Contesse \& M. del Mar Del Torreblanca-Lopez (Eds.): Second language acquisition: Insights into non-native vocabulary teaching and learning (pp. 83-98). Bristol, GB: Channel View Publications.

Mizumoto, Atsushi \& Shimamoto, Taiko (2008): A comparison of aural and written vocabulary size of Japanese EFL university learners. In: Language Education \& Technology, 45, pp. 35-52.

Nagy, William (2007): Metalinguistic awareness and the vocabulary-comprehension connection. In: R. K. Wagner, A. E. Muse \& K. R. Tannenbaum (Eds.): Vocabulary acquisition:Implication for reading (pp. 52-77). New York: Guilford Press.

Nagy, William \& Anderson, Richard. C. (1984): How many words are there in printed school English? In: Reading Research Quarterly, 19, pp. 304-330.

Nagy, William; Berninger, Virginia \& Abbott, Robert (2006): Contributions of morphology beyond phonology to literacy outcomes of upper elementary and middle-school students. In: Journal of Educational Psychology, 98, pp. 134-147.

Nagy, William; Berninger, Virginia; Abbott, Robert; Vaughan, Katherine \& Vermeulen, Karin (2003): Relationship of morphology and other language skills to literacy skills in at-risk second-grade readers and at-risk fourth-grade writers. In: Journal of Educational Psychology, 95, pp. 730-742.

Nation, I. S. P. (2013): Learning Vocabulary in Another Language. New York: Cambridge University Press.

Pasquarella, Adrian; Chen, Xi; Lam, Katie; Luo, Yang C. \& Ramirez, Gloria (2011): Cross -language transfer of morphological awareness in Chinese-English bilinguals. In: Journal of Research in Reading, 34, pp. 23-42

Ramirez, Gloria; Chen, Xi; Geva, Esther \& Luo, Yang (2011): Morphological awareness and word reading in English language learners: Evidence from Spanish- and Chinese-speaking children. In: Applied Psycholinguistics, 32, pp. 601-18.

Schmitt, Norbert; Schmitt, Diane \& Clapham, Caroline (2001): Developing and exploring the behavior of two new versions of the Vocabulary Levels Test. In: Language Testing, 18(1), 55-88. (doi: $10.1177 / 026553220101800103)$ 
Tighe, Elizabeth L. \& Schatschneider, Christopher (2015): Exploring the dimensionality of morphological awareness and its relations to vocabulary knowledge in adult basic education students. In: Reading Research Quarterly, 50(3), pp. 293-311.

Wang, Min; Cheng, Chenxi \& Chen., Shi-Wei (2006): Contribution of morphological awareness to Chinese-English biliteracy acquisition. In: Journal of Educational Psychology, 98, pp. 542-53.

Zeeland, Hilde van (2017): Four studies on vocabulary knowledge in and from listening: Findings and implications for future research. In: Language Teaching, 50(1), pp. 143-150.

Zhang, Dongbo \& Koda, Keiko (2012): Contribution of morphological awareness and lexical inferencing ability to L2 vocabulary knowledge and reading comprehension among advanced EFL learners: testing direct and indirect effect. In: Reading and Writing, 25(5), pp. 1195-1216.

Zhang, Dongbo \& Koda, Keiko (2013): Morphological awareness and reading comprehension in a foreign language: A study of young Chinese EFL learners. In: System, 41(4), pp. 901-913.

Zhang, Dongbo \& Koda, Keiko (2014): Awareness of derivation and compounding in ChineseEnglish biliteracy acquisition. In: International Journal of Bilingual Education and Bilingualism, 17(1), pp. 55-73.

\section{Ahout the Authors}

Prof. Xu Bian: Assistant Professor of Chinese, Seattle Pacific University, Seattle, WA (USA). Contact: bianx@spu.edu

Prof. Jin'e He: Associate Professor, Zhongkai University of Agriculture and Engineering, Guangzhou, Guangdong (China). Contact: he_jine@126.com 